\title{
景观建筑在园林设计中的应用研究
}

\author{
李茌成* \\ 苏交科股份集团有限公司，江苏 210000
}

\begin{abstract}
摘 要: 随着社会经济的发展, 生活水平的不断提高, 人们对于社会环境的要求也随之提高。其中, 园林设计是 提高社会环境的重要人文景观。不仅为城市提增添了新意, 根据设计风格的不同, 还能代表着城市的形象文明, 为城 市提供了休闲娱乐的场所。在整个园林设计中, 景观建筑发挥着至关重要的作用。一个优秀的园林设计与景观建筑是 密不可分的, 一个独具特色的景观建筑会成为园林设计中的标志性建筑, 为原本的园林设计锦上添花, 使其设计内容 变得多种多样。
\end{abstract}

关键词: 景观建筑; 园林设计; 应用策略

\section{Application of Landscape Architecture in Landscape Design}

\author{
Rui-Cheng Li* \\ Jiangsu Transportation Institute, Nanjing 210017, Jiangsu, China
}

\begin{abstract}
With the economic development of the society and the constant improvement of people's living standards, the requirements for the social environment are also increasing. Among them, landscape design is an important cultural landscape to improve the social environment. It not only adds new ideas to the city, but also represents the image civilization of the city according to different design styles, as well as provides a place for leisure and entertainment for the city. Landscape architecture plays a vital role in the entire landscape design. An excellent landscape design and landscape architecture are inseparable. A unique landscape architecture will become a landmark in the landscape design, which will make the original landscape design more beautiful and add a variety of content in the garden design.
\end{abstract}

Keywords: Landscape architecture; landscape design; application strategy

\section{一、引言}

随着我国综合国力的不断提升, 社会经济水平也在飞速发展, 人们在物质生活需求不断的得到满足的同时对精神 生活方面的需求在不断加强。通过园林设计与其中景观建筑的相结合, 能够有效的满足人们对精神生活方面的需求, 并展示出城市园林的设计魅力。在进行园林设计时, 需要综合考虑很多方面的内容。其中不仅要涉及建筑, 利用好现 有的自然景观也极为重要。在现有的自然景观条件下, 对人为因素进行合理的规划和设计, 才能使园林景观更具有艺 术性，使园林景观富有观赏性跟美感。

\section{二、景观建筑在园林设计中的重要意义}

完美的园林设计应当将自然景观与人文景观相结合, 这样不仅能给园林设计增加观赏感, 还能使园林设计更符合 现在人们的需求。景观建筑是园林设计中的主体, 占据核心地位。景观建筑的设计要满足园林设计的需求, 达到自然 景观与人文景观的协调与融合。人们在游玩的过程中不仅能够被自然景色所吸引, 还很容易被建筑景观所吸引, 通过 合理的设计规划将建筑景观设计的独具特色、相互联系, 这样能够满足人们的赏景需求 ${ }^{[1]}$ 。优秀的景观建筑在一定程 度上能够在视觉方面扩大园林的空间感。通过景观建筑与自然景色相组合，体现园林设计的层次感。由于现代发达的 旅游业, 园林成为了现代人们观赏的重要景点。根据这一特点需要在园林设计时考虑到各种设施的放置, 不仅要为人 们设计出休息的场所, 还需要提供娱乐以及服务的场所等等。通过景观建筑合理的设计和布局能够丰富园林设计中的 内容, 使提原本为人们提供的休息场所、服务场所、娱乐场所等地方相互协调, 达到独特的视觉艺术效果, 进而提升 园林的观赏质量。

*通讯作者: 李炳, 1991 年 2 月, 男, 汉族, 江苏省连云港市人, 任职于苏交科股份集团有限公司, 四级工程师, 助理工程, 本科。研究方向: 园林景观。 


\section{三、景观建筑在园林设计中的功能与应用}

景观建筑不但要满足各种使用需求, 除观赏性之外, 部分景观建筑还应该具备为人们提供服务的功能, 兼具观赏 与被观赏的功能。这要与园林设计主题相符，将景观建筑与自然风光完美结合。

(一) 景观建筑在园林设计中的功能

从建筑学来说，景观建筑的功能分为四大块：点景、赏景、引导和空间分割。

点景应将景观建筑融人到自然中, 控制整个园林设计的布局形式; 在园林设计的全景构图中, 景观建筑起着举足 轻重的功能。赏景是能够欣赏到园林的景物, 景观建筑是画面的焦点, 然而一组连接建筑的游廊却是一道很好的观赏 线。引导功能: 景观建筑有着很好的承接作用, 当人们被一处景观建筑吸引时, 就会不自觉的延伸欣赏路线, 这种时 候景观建筑往往能起到很好的引导作用。空间分割: 园林设计的关键在于空间的组合与布局, 通过利用花墙、庭院、 门洞、以及游廊等景观建筑能够很好的对空间进行分划或组合，使人获得美好的艺术感官 ${ }^{[2]}$ 。

(二) 景观建筑在园林设计中的应用

1. 亭的设计与应用

对于园林设计而言, 景观凉亭是其中最重要的景观建筑之一。其表现形式多种多样, 通过与水、花、草、丘等不 同的景色相结合能够达到不同的效果, 为整个园林设计增添更多的意境。周围风景秀美, 很难不让人感受到美好的景 色, 仿佛置身于诗中的风光之中, 给人留下无限的想象与享受空间, 能让人们留下足够深刻的印象 ${ }^{[3]}$ 。除此之外, 它 有一个至关重要的功能。在人们劳累的时候, 凉亭是能让人一眼发现特别又舒适的休息场所, 还能在特殊情况下提供 避雨、乘凉等功能。凉亭在园林设计中可以分成两种风格。一种是传统风格凉亭, 传统凉亭的形状主要有梅花形、多 边形等形状; 在凉亭顶部以单屋檐和双屋檐为主, 有的时候也会用多重屋檐的形式进行设置。另外一种就是现代风格 凉亭, 现代凉亭的形式更加丰富。顶部大多设置为平面图形、弧形和坡面结构等形态, 顶的形状与亭的多种形状可以 自由结合衍生出形色各异的凉亭, 更加雄伟、精致, 带给人们对于美的极致享受。凉亭的建筑材料主要有木料、石料 以及钢筋混凝土等。不同的材料能够带来不同的感觉, 木料的简约朴素, 石料的硬朗, 混合材料根据情况的不同带来 的感受也不相同 ${ }^{[4]}$ 。凉亭想要发挥出最大的作用, 应该设在周围景色优美的地方, 尤其是有流水经过的地方, 依水而 建。亭内空气清新，亭外流水经过，能给人们带来赏心悦目的感受（如图1所示）。

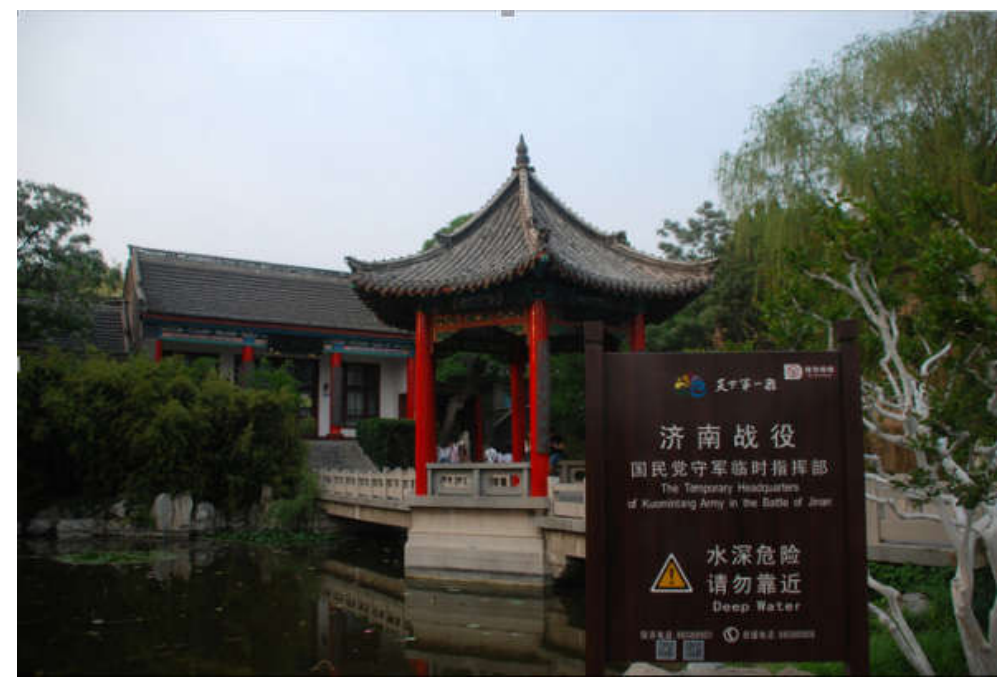

图1 济南大明湖公园凉亭

\section{2. 桥的设计与应用}

在园林设计中水是不可或缺的一部分，除了观赏的作用外还能带给人活力。为了连接流水的两岸，让人们能够更 近距离的接触到水, 桥就发挥了至关重要的作用。因此在园林设计中常常需要桥梁的应用, 这也让桥梁成为了园林设 计最重要的景观建筑之一。桥梁除了是行走的路之外, 也可以看作是景色的一部分。人们想要接近水流, 近距离观赏 水流的美丽之处, 最好的办法就是在水面上架一座桥 ${ }^{[5]}$ (如图2所示)。在提高景观的欣赏性同时, 又能够提高园林设 计的简约性。桥在观赏的艺术方面远远超过它的交通性。比如扬州瘦西湖上的五亭桥——将桥与亭相结合, 桥不仅是 桥, 还是凉亭, 甚至能将其看作富有韵律的建筑群。园林设计里的桥在视觉上对空间进行了分隔, 然而在现实中又是 连接两个空间的道路, 站在桥上看着水中的倒影, 能给人们带来无限的遐想空间。桥的合理设计还可以扩展景观的面 
积, 增加景观的层次感。在小型的园林设计中可以将桥设计成精致的拱形桥, 并且要与水面接近, 让人们更加亲近自 然接触自然; 在大型的园林中, 就更要重视对桥的设计。如果桥的设计具有特色, 甚至会成为园林中的标志性建筑, 让人们对之记忆犹新。为了体现园林设计的协调性与统一性, 根据周围情况的不同, 还可以设计出不同风格的桥, 使 其更加接近园林的主体风格。并且能够使景观建筑与自然景观巧妙的融为一体, 使园林设计的观赏性不断增强。在园 林设计时要经过实地考察, 根据周围环境, 水的流向等要素在合适的位置搭建桥梁, 保证人们在观赏的同时又能做到 与其他景观相协调 ${ }^{[6]}$ 。在设计桥梁时, 一定要根据整体结构进行规划, 设计出最适合园林风格的桥梁, 并且根据场景 的不同选用最合适的建设材料。

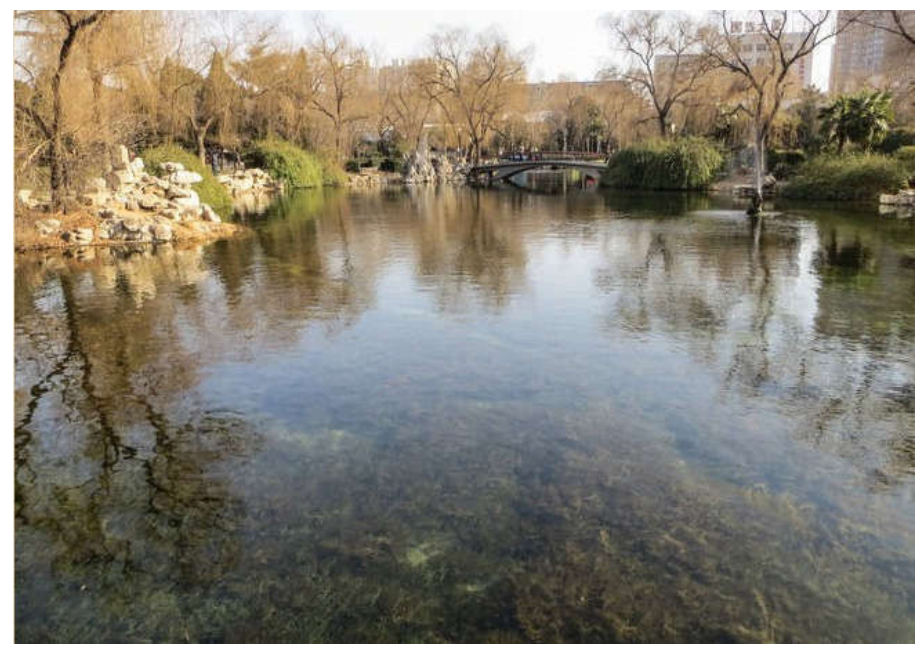

图2 西苑公园桥和水

\section{3. 廊的设计与应用}

廊是连接两个建筑, 是一个具有过渡性质的空间, 甚至是两个空间的主要通道。不仅能使园林设计的层次感变 强, 还能延长人们的游玩时间。在实际的作用上, 由于廊的顶部有遮盖物设计, 除了连接功能之外, 还能进行遮风避 雨与休憩一人们在廊中行走时, 可以对周围的其他景观进行观赏。在设计过程中, 大多数情况会将廊设计成多种风 格，其中有空廊、半廊和双边廊等。不仅能给人们提供休䟤的空间，还能将其打造成独具特色的景观建筑。在廊的设 计规划时, 要注意廊的走向与长度, 还应该充分利用好绿色植被。将廊与绿色植被相结合形成郁郁葱葱的外部结构, 让廊映衬在绿色的植物中, 使人走在里面享受清凉, 起到一定的遮阳效果, 营造出人与自然融洽相处的景象。合理的 走廊设计还能够发挥出停留的作用, 让人们置身其中, 流连忘返, 增加人们的游玩时间, 充分感受到人与景相融的意 境 ${ }^{[7]}$ 。我国园林设计中, 最具有代表意义的莫过于位于岭南地区, 被称为四大园林之一的 “浣红跨绿” 桥廊。它完美 的阐释了廊在园林景观中的作用和意义（如图3所示）。

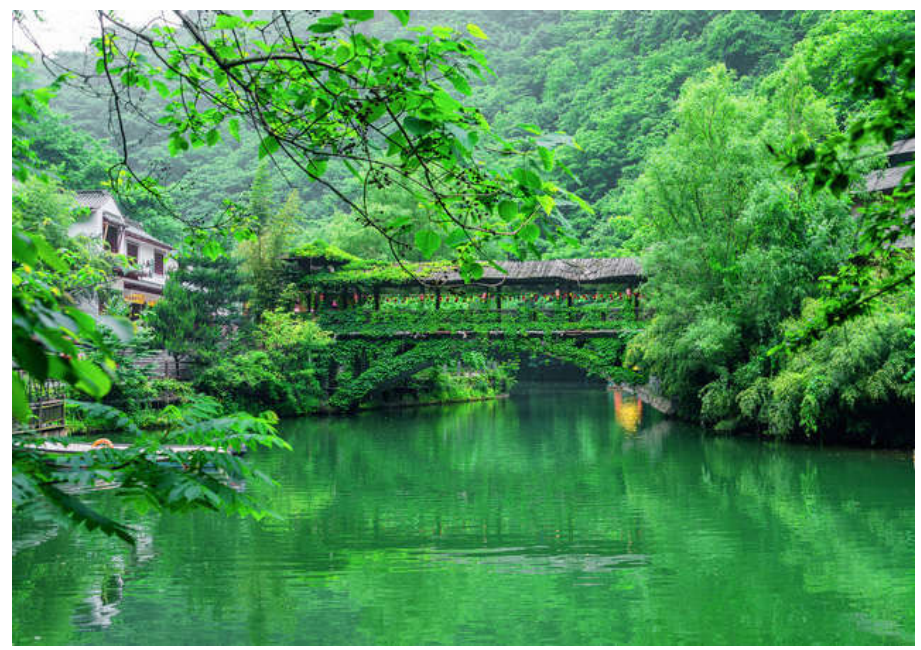

图3 风雨桥廊 


\section{4. 其他景观建筑的设计与应用}

在城市人口愈来愈集中的情况下，园林的规模与人流量以及在人流集中上都在不断加强。其中售票厅、商店和公 则等建筑必不可少, 在考虑功能的基础上还要进行科学的外立面设计, 结合生态环境与园林主题的需求, 将其设计成 完美融人到园林中的建筑风格; 不会因为建筑风格不同而显的格格不人, 破坏人们赏景的心情与意境。在体现地域风 情方面，应该更宜加强地域文化元素 ${ }^{[8]}$ 。

\section{四、景观建筑在园林设计中的所用方法}

要想使景观建筑在园林设计中发挥出重要积极的作用，为园林设计带来更大的视觉享受，就应该采取合理有效的 办法, 使园林设计趋近完美。首先, 是园林设计中的景观建筑的立意。立意往往会根据设计者的知识、喜好、经验以 及想象等因素产生不同。在设计时应该先考虑好整体园林的景观意境, 促使园林中的景观建筑更加和谐; 其次是园林 设计中的选址。由于园林设计不仅仅是人造景观, 更重要的是自然景观, 因此选址在园林设计中占据了一个十分重要 的地位。选出一个上风上水的好地址, 搭配上景观建筑, 才能使整个园林设计更加自然和谐。在选址时还要详细了解 所选地区的土质、风向、水质等问题，只有把这些都考虑完善才能展现出园林设计中景观建筑的特色与魅力。

\section{五、结语}

园林设计是一件综合性很强的工作，对设计者的要求也颇高。在园林设计过程中不仅需要自然景观，景观建筑的 作用也十分重要。因此将两者进行完美的融合是园林设计中至关重要的部分, 也是对设计者的一个考验。只有对自然 景观与景观建筑进行综合考虑, 发挥出设计者的想象力, 实现两者之间的完美融洽与搭配, 才能够使整个园林在保持 宁静优雅的同时，还能突显出浓郁的人文气息和文化底蕴。

\section{参考文献:}

[1]郭艳杰.景观建筑在园林设计中的应用浅述[J].建材与装饰, 2019(27):66-67.

[2]李宇波.景观建筑在园林设计中的应用浅述 [J]. 山西建筑, 2019,45(01):183-185.

[3]韦薇.景观建筑在园林设计中的应用 [J].山西建筑, 2018,44(36):180-181.

[4]云静.园林设计中景观建筑的应用[J].现代园艺, 2018(20):131.

[5]梁惠,刘琳.景观建筑在园林设计中的应用[J].现代园艺, 2018(18):123.

[6]彭学锋.景观建筑在园林设计中的应用探讨[J].现代园艺, 2018(10): 111 .

[7]王勇.景观建筑在园林设计中的应用解析[J].现代园艺, 2018(08):92.

[8]钱晓丽.景观建筑在园林设计中的应用分析[J].现代园艺, 2017(20):112. 